\title{
Texture Profile Analysis of Sliced Cheese in relation to Chemical Composition and Storage Temperature
}

\author{
Yuanrong Zheng, Zhenmin Liu, and Beihong Mo \\ State Key Laboratory of Dairy Biotechnology, Technical Center of Bright Dairy \& Food Co., Ltd., Synergetic Innovation \\ Center of Food Safety and Nutrition, Shanghai 200436, China
}

Correspondence should be addressed to Zhenmin Liu; liuzhenmin@brightdairy.com

Received 10 October 2015; Revised 1 February 2016; Accepted 6 April 2016

Academic Editor: Shaoyang Liu

Copyright (C) 2016 Yuanrong Zheng et al. This is an open access article distributed under the Creative Commons Attribution License, which permits unrestricted use, distribution, and reproduction in any medium, provided the original work is properly cited.

\begin{abstract}
The quantitative relationships among chemical composition, storage temperature, and texture of cheese were not fully understood. In this study, the effects of composition and temperature on textural properties of eight common varieties of sliced cheese were examined. The textural properties of sliced cheeses, including firmness, cohesiveness, adhesiveness, springiness, chewiness, and resilience, were measured by texture profile analysis after storage at 4 and $25^{\circ} \mathrm{C}$ for $4 \mathrm{~h}$. Multivariate logistic regression models were established to describe the quantitative relationships of textural properties (dependent variables) to chemical composition and storage temperature (independent variables) of sliced cheeses. Results showed that protein, fat, moisture, and sodium chloride contents as well as storage temperature significantly affected the texture of sliced cheeses $(P<0.05)$. In particular, fat in the dry matter and moisture in the nonfat substances were negatively correlated with firmness of sliced cheeses $(P<0.05)$. As storage temperature rose from 4 to $25^{\circ} \mathrm{C}$, the average values of firmness, chewiness, and resilience substantially declined by $42 \%$, $45 \%$, and $17 \%$, respectively $(P<0.05)$. This study provided reference data for adjusting chemical composition and storage temperature of common cheese products to obtain favorable texture for Chinese consumers, which thereby facilitated the localization of cheese industry in Chinese market.
\end{abstract}

\section{Introduction}

Texture was an important indicator for evaluating cheese quality and functional characteristics, which was also commonly used to differentiate many varieties of cheese. Cheese texture is considered to be a determinant of the overall opinion and preference of the consumers $[1,2]$. The major approaches for analyzing cheese texture were sensory evaluation and instrumental measurements. The former approach was time-consuming and required extensive training of panelists; thus, the latter approach had often been chosen for routine analysis of cheese texture [3]. Texture profile analysis (TPA) worked effectively for analyzing and predicting sensory attributes of cheese. Numerous studies confirmed that the results of instrumental TPA correlated well with sensory evaluation data of cheese texture [4-6].

Chemical composition was one of the most important factors influencing cheese quality. In the manufacture of natural cheese, different processing conditions of strain culture, heating temperature, salting, stretching, and ripening would cause variations in the chemical composition of the products $[7,8]$. Protein, fat, and moisture were the three major constituents of cheese, which comprise more than $80 \%$ mass and directly affected textural and functional properties of cheese [9-12]. For example, there existed great differences in the firmness and springiness of Cheddar cheese with varying fat contents (low-fat, $6 \%$; reduced-fat, $16 \%$; and fullfat, $33 \%)$ at the ripening stage [13]. Additionally, sodium chloride $(\mathrm{NaCl})$ had a direct effect on cheese texture and rheology, because $\mathrm{NaCl}$ addition increased the amount of the matrix as well as casein hydration and solubilization via calcium displacement $[14,15]$.

Cheese was a traditional and popular manufactured food product. Natural cheese took a leading role $(>80 \%)$ in the market share in western countries. On the contrary, processed cheese took above 90\% market share in China, of which 
$60 \%$ was sliced cheese (source: After International Dairy Federation). In cheese processing, the proportion of moisture, fat, protein, and $\mathrm{NaCl}$ could be manipulated conveniently by blending other diary (e.g., cream, butter, skim-milk powder, and whey powder) and nondairy ingredients (e.g., vegetable oil, ham, fish, and $\mathrm{NaCl}$ ) which was convenient in processed cheese products [16]. Therefore, any changes in chemical compositions must also be taken into consideration for evaluating cheese texture.

Storage temperature was another important factor affecting cheese quality. Cheese was preferentially stored and distributed at $2-8^{\circ} \mathrm{C}$. In China, temperature control in cheese storage was often not so good that the interruption of the cold chain and potential temperature which rose to the ambient level $\left(25^{\circ} \mathrm{C}\right)$ might cause substantial changes in sensory and texture properties of cheese [14]. Many studies investigated the effect of temperature on the flavor, color, and oxidative stability of processed cheese [17]. The shelf life of processed cheese stored at ambient temperature might be shortened considerably due to lipid oxidation and/or nonenzymatic browning [17]. However, few studies focused on the quantitative relationship between cheese texture and storage temperature, leading to difficulties in the manufacturing of favorable cheese products involving temperature adjustment.

The objectives of this study were (1) to investigate the quantitative relationships of chemical composition and storage temperature to texture properties of eight common varieties of sliced cheese and (2) to identify the feasibility and possible benefits of sensory assessment of cheese. The textural properties of sliced cheeses were measured by texture profile analysis (TPA) after storage at different temperatures for a certain period. Multivariate logistic regression models were established to describe the quantitative relationships of textural properties to chemical composition and storage temperature of sliced cheeses. The results will provide reference data for adjusting chemical composition and storage temperature of common cheese products to obtain favorable texture for Chinese consumers, thereby facilitating the localization of cheese industry in Chinese market.

\section{Materials and Methods}

2.1. Cheese Samples. Eight varieties of sliced cheese (lowfat Cheddar; high-calcium Cheddar; Cheddar 1; Cheddar 2; Emmental 1; Gouda; Emmental 2; and reduced-fat Cheddar) were purchased from a local grocery store in Shanghai, China. All of the sliced cheeses were cut into cubes $(5 \mathrm{~cm} \times 5 \mathrm{~cm} \times$ $1 \mathrm{~cm}$ ) and wrapped with plastic film to minimize moisture losses. The samples were divided into two groups and then stored at $4^{\circ} \mathrm{C}$ in a refrigerator and at $25^{\circ} \mathrm{C}$ for $4 \mathrm{~h}$ prior to analysis.

2.2. Proximate Analysis. The proximate analysis of the cheese samples was carried out following standard methods of AOAC [18]. About $100 \mathrm{~g}$ of cheese was taken from various parts of the cheese mass for analyzing. Total protein in cheese was determined by measuring total nitrogen using the Kjeldahl method [19] with a Kjeltec Auto Analyzer

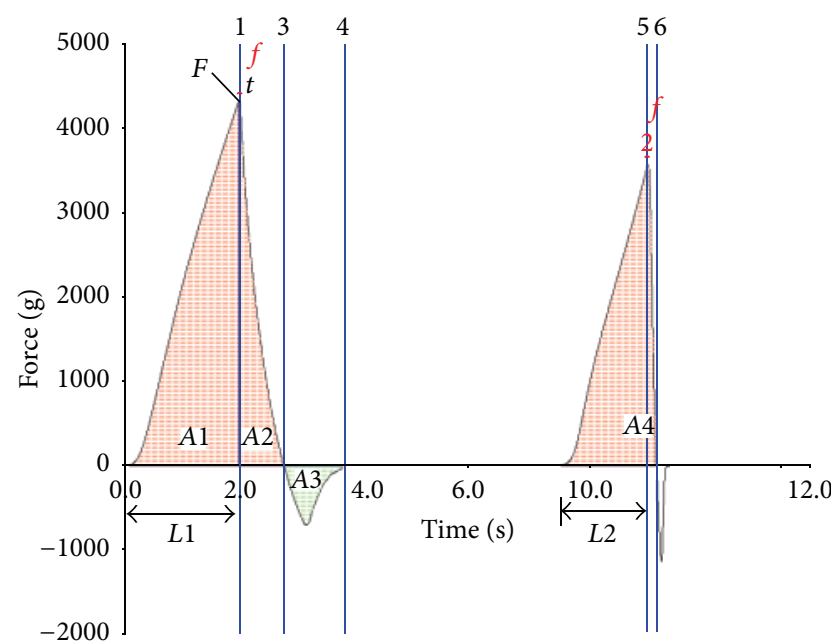

FIgure 1: Texture profile analysis curve of sliced cheese. The calculation of textural properties: firmness $=F(\mathrm{~g})$, springiness $=$ $L 2 / L 1$, cohesiveness $=A 4 /(A 1+A 2)$, adhesiveness $=A 3(\mathrm{~g} \cdot \mathrm{s})$, resilience $=A 2 / A 1$, and chewiness $=$ firmness $\times$ cohesiveness $\times$ springiness (g).

(Model 2400, Tecator, Hoganas, Sweden) and converting with a multiplication factor of 6.38. The fat content of cheese samples was determined using the Gerber method [20]. To determine total moisture content, the samples were weighed into aluminum pans and dried in a $70^{\circ} \mathrm{C}$ vacuum oven $(92 \mathrm{kPa})$ for $4 \mathrm{~h}$ following a modified version of method in the Association of Official Analytical Chemists [19, 21]. $\mathrm{NaCl}$ content was determined by colorimetric titration with a chloride analyzer (model 926, Corning, Medfield, MA, USA). All chemical measurements were carried out in triplicate. Fat in dry matter (FDM, \%) was calculated as fat/(100 moisture) $\times 100$, moisture in nonfat substance (MNFS, \%) was calculated as moisture/(100 - fat $) \times 100$, and salt in moisture (S/M, \%) was calculated as salt/moisture $\times 100$.

2.3. Texture Profile Analysis. TPA of sliced cheese was performed using a texture analyzer (model TA-Hdi, Stable Micro Systems, Godalming, UK) with a $10 \mathrm{~kg}$ force load cell. A double-bite compression cycle (Figure 1) was carried out with a rest period of $5 \mathrm{~s}$ between bites. Optimized test conditions were SMSP/25 probe, $25 \mathrm{~mm}$ diameter cylinder; test speed, $1 \mathrm{~mm} / \mathrm{s}$; pretest speed, $2 \mathrm{~mm} / \mathrm{s}$; posttest speed, $5 \mathrm{~mm} / \mathrm{s}$; distance, $2.0 \mathrm{~cm}$ making the cheese samples fractured; and trigger force, $0.020 \mathrm{~g}$. Each cheese sample was measured for 26 replicates. Data collection was accomplished using Texture Expert (version 1.22, Stable Micro System, Haslemere, Surrey, UK). TPA parameters were determined according to Bourne [22].

2.4. Data Analysis. Cheese textural properties, including firmness, adhesiveness, springiness, cohesiveness, chewiness, and resilience, were calculated using Texture Exponent 32 (Stable Micro Systems Ltd., Godalming, UK). The data of chemical composition and textural properties were analyzed using PROC REG analysis and the prediction model was 
TABLE 1: Chemical compositions of eight varieties of sliced cheese.

\begin{tabular}{lcccc}
\hline Cheese variety & Protein (\%) & MNFS (\%) & FDM (\%) & S/M (\%) \\
\hline Low-fat Cheddar & $18.5 \pm 1.06^{\mathrm{a}}$ & $57.5 \pm 1.51^{\mathrm{e}}$ & $22.5 \pm 1.13^{\mathrm{e}}$ & $2.8 \pm 0.12^{\mathrm{a}}$ \\
High-calcium Cheddar & $17 \pm 1.52^{\mathrm{c}}$ & $66.8 \pm 2.78^{\mathrm{b}}$ & $51.7 \pm 2.01^{\mathrm{a}}$ & $2.2 \pm 0.18^{\mathrm{b}}$ \\
Cheddar 1 & $17.2 \pm 0.71^{\mathrm{bc}}$ & $67.0 \pm 3.65^{\mathrm{b}}$ & $51.7 \pm 1.57^{\mathrm{a}}$ & $2.2 \pm 0.21^{\mathrm{b}}$ \\
Cheddar 2 & $17.9 \pm 1.30^{\mathrm{ab}}$ & $66.4 \pm 4.03^{\mathrm{bc}}$ & $43.9 \pm 0.92^{\mathrm{bc}}$ & $1.4 \pm 0.09^{\mathrm{cd}}$ \\
Emmental 1 & $17.6 \pm 1.23^{\mathrm{bc}}$ & $63.7 \pm 2.09^{\mathrm{c}}$ & $40.5 \pm 1.35^{\mathrm{c}}$ & $0.9 \pm 0.12^{\mathrm{d}}$ \\
Gouda & $18.5 \pm 1.25^{\mathrm{a}}$ & $63.9 \pm 3.62^{\mathrm{c}}$ & $43.3 \pm 0.75^{\mathrm{bc}}$ & $1.2 \pm 0.07^{\mathrm{d}}$ \\
Emmental 2 & $12 \pm 0.93^{\mathrm{e}}$ & $71.0 \pm 4.02^{\mathrm{a}}$ & $46.9 \pm 1.24^{\mathrm{b}}$ & $1.2 \pm 0.11^{\mathrm{d}}$ \\
Reduced-fat Cheddar & $16 \pm 0.67^{\mathrm{d}}$ & $61.1 \pm 3.11^{\mathrm{d}}$ & $32.7 \pm 0.89^{\mathrm{d}}$ & $1.9 \pm 0.08^{\mathrm{bc}}$ \\
\hline
\end{tabular}

Means within the same row not sharing common superscript letters are significantly different $(P<0.05)$.

MNFS: moisture in the nonfat substances, FDM: fat in the dry matter, S/M: salt in moisture.

The values of each composition are expressed as mean \pm standard deviation of the mean $(n=3)$.

built using stepwise linear regression analysis in SAS 9.2 (SAS Institute, Cary, NC, USA). Using stepwise linear regression, the independent variable not in the equation that had the smallest probability of $F$ was entered at each step, if that probability was sufficiently small. Variables already in the regression equation were removed if their probability of $F$ became sufficiently large. The method terminated when no more variables were eligible for inclusion or removal. In the regression analysis, textural properties were taken as the dependent variables, and chemical composition and temperature were taken as the independent variables. The program first selected the most significant independent variable $(P<$ 0.05 ) followed by the second most significant independent variable $(P<0.05)$, and so on, in a stepwise fashion [23].

\section{Results and Discussion}

3.1. Chemical Composition of Sliced Cheese. The chemical composition of natural cheese was affected by various factors such as raw milk composition, curd handling, cooking, and salting, whereas that of processed cheese was strongly controlled by the variety of natural cheese as well as the amount of solid matter and water added [14].

In the eight varieties of sliced cheese under study, moisture comprised approximately $50 \%$ of total mass, and the percent moisture in nonfat substances (MNFS) varied from 57.5 to $71.0 \%$ (Table 1). Compared with moisture content, the MNFS level was considered to have a more direct relationship to cheese properties and was among the most important factors affecting cheese quality [24]. The lowest MNFS values were found in low-fat and reduced-fat Cheddar $(\sim 60 \%)$, with the highest values in Emmental 2 and Cheddar $1(\sim 70 \%$, Table 1). The lower the MNFS level was, the higher the protein concentration and the number of intermolecular bonds were [25]. It was suggested that the ratio of casein to water rather than the fat level has a major effect on meltability of casein gels [25].

Fat content of cheese was often expressed as fat in the dry matter (FDM) which was responsible for desirable functional, textural, and sensory properties of cheese [24]. In the present study, FDM varied from 22.5 to $51.7 \%$ in the eight varieties of sliced cheese (Table 1). Statistical data showed that the FDM values were significantly lower in low-fat and reduced-fat Cheddar than in the other varieties of sliced cheese $(P<$ $0.05)$, consistent with the MNFS data mentioned above.

Excessive dietary sodium intake was not good for health. Being a minor constituent of cheese, typical amount of $\mathrm{NaCl}$ as indicated by the salt in moisture $(\mathrm{S} / \mathrm{M})$ ranges from 1.8 to $2.1 \%$. As for the sliced cheeses tested, $\mathrm{S} / \mathrm{M}$ was generally less than $2.8 \%$ (Table 1). This parameter is directly linked to $\mathrm{NaCl}$ and moisture levels in cheese. Elevation of S/M may increase the possibility for replacement of $\mathrm{Ca}^{2+}$ with $\mathrm{Na}^{+}$, thereby decreasing the firmness of cheese. Additionally, S/M was considered to be strongly related to texture, rheology, and flavor [15].

Protein in processed cheese is mainly casein, which was the only continuous phase in cheese and forms a honeycomblike network directly through calcium bridge. The caseinbased network structure provided a matrix for fat, moisture, and salt [14]. In the sliced cheeses tested, the protein content generally ranged from 16 to $18.5 \%$, with an exceptionally low level in Emmental 2 (12\%, Table 1). According to the literature, protein content and distribution affected the texture of cheese. The lower the protein content, the higher the firmness of cheese. Thus, our protein data indicated that Emmental 2 had the lowest firmness among the cheese varieties tested.

3.2. Cheese TPA Properties in relation to Chemical Composition and Storage Temperature. Table 2 shows the firmness of sliced cheeses tested in relation to different chemical compositions and storage temperatures. Firmness was the force needed to attain a given deformation [26]. In sensory terms, it was the force required to compress a cheese with the molars to the point of penetration [27]. It could be seen that low-fat and reduced-fat Cheddar have significantly higher firmness than the other varieties $(P<0.05$, Table 2$)$, corresponding to their lowest MNFS and FDM values $(P<$ 0.05). On the contrary, Emmental 2 and Cheddar 1 had the lowest firmness among the eight varieties $(P<0.05)$, coincident with the highest MNFS and FDM values $(P<$ 0.05). Additionally, the average firmness of sliced cheeses declined by $42 \%$ when the storage temperature rose from 4 to $25^{\circ} \mathrm{C}$ (Table 2). 
TABLE 2: Firmness of eight varieties of sliced cheese at different storage temperatures.

\begin{tabular}{|c|c|c|c|c|c|c|c|c|}
\hline Temperature $\left({ }^{\circ} \mathrm{C}\right)$ & LFC & $\mathrm{HCC}$ & CA & $\mathrm{CB}$ & EA & G & EB & RFC \\
\hline 4 & $4079 \pm 278^{\mathrm{a}}$ & $2060 \pm 208^{\mathrm{d}}$ & $1744 \pm 136^{\mathrm{e}}$ & $2240 \pm 115^{\mathrm{d}}$ & $2193 \pm 170^{\mathrm{d}}$ & $2900 \pm 177^{\mathrm{c}}$ & $1458 \pm 91^{\mathrm{fg}}$ & $3346 \pm 143^{\mathrm{b}}$ \\
\hline 25 & $2735 \pm 198^{\mathrm{c}}$ & $997 \pm 74^{\mathrm{i}}$ & $973 \pm 83^{\mathrm{i}}$ & $1256 \pm 63^{\mathrm{gh}}$ & $1215 \pm 109^{\mathrm{h}}$ & $1617 \pm 160^{\text {ef }}$ & $974 \pm 39^{\mathrm{i}}$ & $2070 \pm 214^{\mathrm{d}}$ \\
\hline
\end{tabular}

Means within the same row not sharing common superscript letters are significantly different $(P<0.05)$.

LFC: low-fat Cheddar, HCC: high-calcium Cheddar, CA: Cheddar 1, CB: Cheddar 2, EA: Emmental 1, G: Gouda, EB: Emmental 2, RFC: reduced-fat Cheddar. The values of firmness are expressed as mean \pm standard deviation of the mean $(n=9)$.

The firmness of the eight varieties of sliced cheese was correlated with chemical composition and storage temperature as follows:

$$
\begin{aligned}
\text { Firmness }= & 10632-101.1(\mathrm{MNFS})-33.6(\mathrm{FDM}) \\
& -48.7(\text { Temperature }) .
\end{aligned}
$$

Equation (1) showed that the firmness of sliced cheese had an inverse relationship with MNFS, FDM, and storage temperature. That is, decrease in MNFS, FDM, or storage temperature contributed to an increase in the firmness of sliced cheese. Specifically, fat in cheese was mainly butter with a melting point of approximately $34^{\circ} \mathrm{C}$. Butter turned soft gradually as the temperature rose, leading to structural changes and even collapse of cheese. Texture attributes were influenced by the nature of protein matrix resulting from fat removal [28]. Therefore, fat content affected cheese firmness significantly, and firmness of cheese products could be effectively controlled by adjusting fat content during product manufacturing.

The adhesiveness of different varieties of sliced cheese is indicated in Table 3. Adhesiveness was the work needed to overcome attractive force between food and other surfaces [26], which, in sensory terms, was the degree to which the sample sticks to your teeth as mastication progresses [21]. The negative sign of adhesiveness values meant stress directed down.

As temperature rose from 4 and $25^{\circ} \mathrm{C}$, the adhesiveness varied among the sliced cheeses tested. The adhesiveness increased with temperature rising by $42 \%$ in Cheddar 1 and by $25 \%$ in Emmental 2 (Table 3), both of which had the lowest firmness (Table 2) and highest FDM (Table 1). However, the adhesiveness of low-fat Cheddar, Cheddar 2, and reducedfat Cheddar declined with temperature rising by $19 \%, 25 \%$, and $33 \%$, respectively, in relation to the highest firmness and lowest FDM. The adhesiveness was influenced by the fat content. When the temperature rose the structure of the full-fat cheese changed and the fat turned soft and increased the adhesiveness. However, the fat of the low-fat cheese was blocked and that reduced the adhesiveness. The adhesiveness of the eight varieties of sliced cheese was correlated with chemical composition and storage temperature as follows:

$$
\begin{aligned}
\mid \text { Adhesiveness } \mid= & 363.0-31.7(\text { Protein })+6.0(\text { FDM }) \\
& +122.8(\mathrm{~S} / \mathrm{M}) .
\end{aligned}
$$

In (2), cheese adhesiveness correlated negatively with protein content and positively with FDM and S/M levels. Fat presented as globules contained within the protein matrix network in cheese curd, acting as a plasticizer to inhibit the formation of cross-links between the casein chains [29]. Lower protein and higher fat contents allowed cheeses to melt better and thus increase the adhesiveness. It was reported that the adhesiveness rose when the S/M rose [12]. Similarly increasing potassium salts was found to increase the adhesiveness too, and this may be related to the observed increases in fat globule size and $\mathrm{pH}$ value [30].

For cheese consumption, appropriate adhesiveness was good for taste and flavor releasing. However, excessively high adhesiveness would cause the problems of cheese package sticking and cheese adhesive to the moderate defect [31]. In this context, adhesiveness played an important role in the quality of sliced cheese and the control of cheese adhesiveness was thus meaningful.

The springiness of eight varieties of sliced cheese was presented in Table 4. In sensory terms, springiness referred to the degree to which the sample returned to the original shape after partial compression between the tongue and hard palate [21].

As storage temperature rose from 4 to $25^{\circ} \mathrm{C}$, an average value of springiness decreased by $7 \%$ in the sliced cheeses tested (Table 4). The springiness of Cheddar 2 and lowfat Cheddar declined by $14 \%$ and $11 \%$, respectively, showing significant differences $(P<0.05)$. The other varieties of cheese showed no significant differences in the springiness with temperature rise $(P>0.05)$.

Previously, Chevanan et al. [12] observed higher springiness in high-calcium and high-phosphorus cheese for the entire testing period of eight months, which might be attributed to more cross-linkages, less proteolysis, and lower moisture in the treatments [12]. In the present study, we found that high-calcium Cheddar's springiness almost had no changes $(-0.007)$ when storage temperature rose from 4 to $25^{\circ} \mathrm{C}$. It was possible that $\mathrm{Ca}^{2+}$ was replaced by $\mathrm{Na}^{+}$ of emulsifying salt, thus decreasing the cross-linkage and further reducing the springiness of cheese.

The springiness of the eight varieties of sliced cheese was correlated with chemical composition and storage temperature as follows:

$$
\begin{aligned}
\text { Springiness }= & 0.264+0.010(\mathrm{MNFS})+0.042(\mathrm{~S} / \mathrm{M}) \\
& -0.003(\text { Temperature }) .
\end{aligned}
$$

Equation (3) indicated that cheese springiness correlated positively with MNFS and S/M but negatively with temperature. However, a previous study suggested that the springiness of both half-fat and low-fat cheese decreased significantly with increasing MNFS [32]. These contradicting results might 


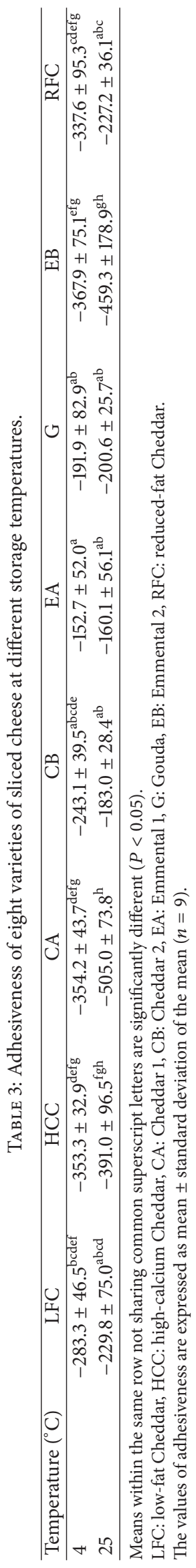




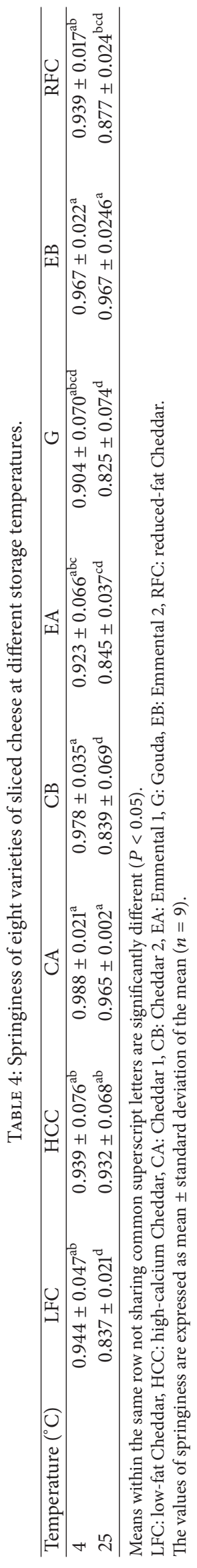




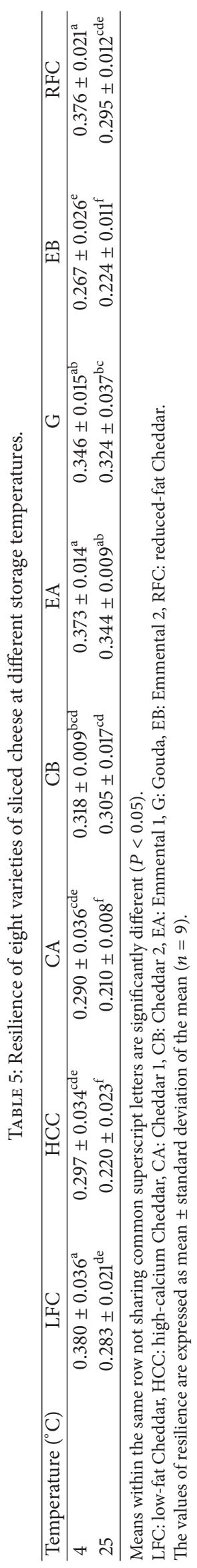




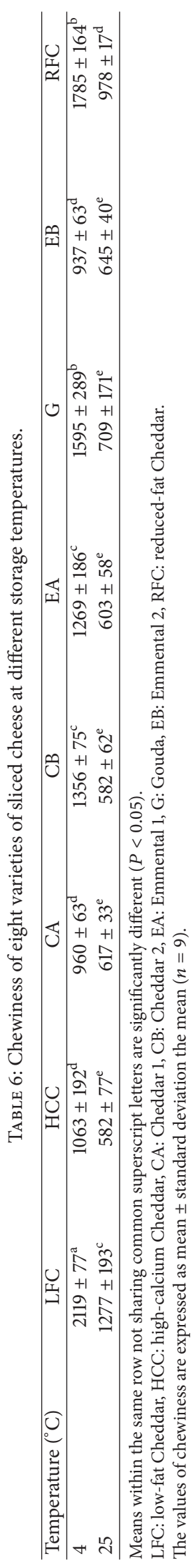


be ascribed to the presence of gums (e.g., carrageenan and xanthan gum), which were usually used to maintain the springiness of cheese and reduce the total solids for cutting the cost.

Resilience, which referred to the degree to which the cheese regains its original shape during the biting process [12], shared a certain similarity with springiness in describing cheese elasticity. There existed at least one difference between resilience and springiness. The former was a measure of ability that the deformed cheese returned to original position after removal of force rapidly, while the latter was a measure of ability that the deformed cheese returned to the initial position after removal of force slowly.

The resilience of eight varieties of sliced cheese is shown in Table 5. As storage temperature rose from 4 to $25^{\circ} \mathrm{C}$, the resilience declined in all varieties of sliced cheeses tested. In particular, the resilience of high-calcium and Cheddar 1 declined by $26 \%$ and $28 \%$, respectively, showing significant differences $(P<0.05)$.

The resilience of eight varieties of sliced cheeses was correlated with chemical composition and storage temperature as follows:

$$
\begin{aligned}
\text { Resilience }= & 1.20-0.012(\mathrm{MNFS})-0.051(\mathrm{~S} / \mathrm{M}) \\
& -0.003(\text { Temperature }) .
\end{aligned}
$$

Equation (4) indicated that cheese resilience correlated negatively with MNFS, S/M, and storage temperature. Thus, the decreased levels of MNFS, S/M, and storage temperature jointly contributed to the higher resilience values in these treatments. Specifically, low MNFS level meant relatively high protein level, which contributed to the resilience of cheese. High S/M level indicated $\mathrm{NaCl}$ content increased, which would increase the possibility of $\mathrm{Ca}^{2+}$ replacement, thereby decreasing the firmness and resilience of sliced cheese. As the storage temperature rose, fat in cheese turns soft, leading to deformation of the product and reduction of its resilience.

Chewiness was a secondary textural parameters of cheese. It was a measure of the work needed to masticate a solid food to a state ready for swallowing [26], which, in sensory terms, was the number of chews that are required before the sample is ready for swallowing [21].

Low-fat cheese samples had high chewiness values while high-fat or high-moisture ones had low chewiness. Average chewiness value significantly declined by $45 \%(P<0.05)$ when storage temperature rose from 4 and $25^{\circ} \mathrm{C}$ (Table 6). The suitable chewiness provides a rich mouth feel and enhances the joy of tasting cheese.

The chewiness of eight varieties of sliced cheese was correlated with composition and temperature as follows:

$$
\begin{aligned}
\text { Chewiness }= & 2815-31.4(\text { FDM }) \\
& -30.3(\text { Temperature }) .
\end{aligned}
$$

Equation (5) indicated that cheese chewiness was correlated negatively with FDM and storage temperature only. The decreased levels of FDM and storage temperature might have important roles in the higher chewiness values in these treatments. This was because chewiness was positively related to the firmness of cheese. The higher the moisture and fat contents were, the lower the firmness of cheese would be. On the contrary, the higher the protein and dry matter contents, the higher the firmness of cheese. As the temperature rose, fat in cheese gradually became softened and thus reduced the firmness of cheese product.

\section{Conclusions}

Chemical composition (protein, fat, moisture, and $\mathrm{NaCl}$ contents) and storage temperature significantly affected the textural properties of sliced cheese. Sliced cheese with higher protein content had lower adhesiveness, whereas fat content (fat in the dry matter) was correlated positively with adhesiveness but negatively with firmness and chewiness of sliced cheese. Low moisture content (percent moisture in the nonfat substances) was associated with higher firmness, and resilience but lower springiness and cohesiveness of sliced cheese. Higher salt content (salt in moisture) caused low resilience and higher adhesiveness and springiness. Storage temperature was correlated negatively with firmness, springiness, chewiness, and resilience of sliced cheese. This study described quantitative relationships between textural properties and chemical composition for common varieties of sliced cheese in Chinese market. In particular, empirical formulae were established for quantitative relationships between storage temperature and cheese texture of eight cheese varieties. The results were thus of guidance value for manufacturing of processed cheese favorable for Chinese customers.

\section{Competing Interests}

The authors declare that they have no competing interests.

\section{Acknowledgments}

This work was financially supported by a Grant from the “Twelfth Five-Year" Plan for National Science and Technology Support Program of China (no. 2013BAD18B02).

\section{References}

[1] K. Wendin, M. Langton, L. Caous, and G. Hall, "Dynamic analyses of sensory and microstructural properties of cream cheese," Food Chemistry, vol. 71, no. 3, pp. 363-378, 2000.

[2] E. A. Foegeding, J. Brown, M. Drake, and C. R. Daubert, "Sensory and mechanical aspects of cheese texture," International Dairy Journal, vol. 13, no. 8, pp. 585-591, 2003.

[3] E. H.-J. Kim, V. K. Corrigan, D. I. Hedderley, L. Motoi, A. J. Wilson, and M. P. Morgenstern, "Predicting the sensory texture of cereal snack bars using instrumental measurements," Journal of Texture Studies, vol. 40, no. 4, pp. 457-481, 2009.

[4] M. A. Drake, P. D. Gerard, V. D. Truong, and C. R. Daubert, "Relationship between instrumental and sensory measurements of cheese texture," Journal of Texture Studies, vol. 30, no. 4, pp. 451-476, 1999. 
[5] M. A. G. Viñas, C. Ballesteros, P. J. Martín-Alvarez, and L. Cabezas, "Relationship between sensory and instrumental measurements of texture for artisanal and industrial Manchego cheeses," Journal of Sensory Studies, vol. 22, no. 4, pp. 462-476, 2007.

[6] R. Di Monaco, S. Cavella, and P. Masi, "Predicting sensory cohesiveness, hardness and springiness of solid foods from instrumental measurements," Journal of Texture Studies, vol. 39, no. 2, pp. 129-149, 2008.

[7] T. C. Rasmussen, D. J. McMahon, J. R. Broadbent et al., "Texture profile analysis and melting in relation to proteolysis as influenced by aging temperature and cultures in Cheddar cheese," Journal of Dairy Science, vol. 90, supplement 1, article 271, 2007.

[8] A. H. Jana and K. G. Upadhyay, "Mozzarella cheese analoguea review," Journal of Food Science and Technology, vol. 40, no. 1, pp. 1-10, 2003.

[9] M. D. Yates and M. A. Drake, "Texture properties of gouda cheese," Journal of Sensory Studies, vol. 22, no. 5, pp. 493-506, 2007.

[10] N. Sahan, K. Yasar, A. A. Hayaloglu, O. B. Karaca, and A. Kaya, "Influence of fat replacers on chemical composition, proteolysis, texture profiles, meltability and sensory properties of low-fat Kashar cheese," Journal of Dairy Research, vol. 75, no. 1, pp. 17, 2008 .

[11] K. Kycia, "Factors moulding the texture of processed cheeses," ZYWN-Nauk Technologia Jakosc, vol. 15, no. 3, pp. 5-17, 2008.

[12] N. Chevanan, K. Muthukumarappan, P. Upreti, and L. E. Metzger, "Effect of calcium and phosphorus, residual lactose and salt-to-moisture ratio on textural properties of cheddar cheese during ripening," Journal of Texture Studies, vol. 37, no. 6, pp. 711-730, 2006.

[13] N. R. Rogers, M. A. Drake, C. R. Daubert, D. J. McMahon, T. K. Bletsch, and E. A. Foegeding, "The effect of aging on lowfat, reduced-fat, and full-fat Cheddar cheese texture," Journal of Dairy Science, vol. 92, no. 10, pp. 4756-4772, 2009.

[14] M. M. Ak and S. Gunasekaran, Cheese Rheology and Texture, CRC Press, 2002.

[15] A. Rulikowska, K. N. Kilcawley, I. A. Doolan et al., "The impact of reduced sodium chloride content on Cheddar cheese quality," International Dairy Journal, vol. 28, no. 2, pp. 45-55, 2013.

[16] I. Piska and J. Štětina, "Influence of cheese ripening and rate of cooling of the processed cheese mixture on rheological properties of processed cheese," Journal of Food Engineering, vol. 61, no. 4, pp. 551-555, 2004.

[17] D. Kristensen, E. Hansen, A. Arndal et al., "Influence of light and temperature on the colour and oxidative stability of processed cheese," International Dairy Journal, vol. 11, no. 10, pp. 837-843, 2001.

[18] AOAC International, Official Methods of Analysis of AOAC International, AOAC International, 2005.

[19] AOAC, Official Methods of Analysis, AOAC, Arlington, Va, USA, 1995.

[20] J. Rahimi, A. Khosrowshahi, A. Madadlou, and S. Aziznia, "Texture of low-fat Iranian white cheese as influenced by gum tragacanth as a fat replacer," Journal of Dairy Science, vol. 90, no. 9, pp. 4058-4070, 2007.

[21] E. A. Gwartney, D. K. Larick, and E. A. Foegeding, "Sensory texture and mechanical properties of stranded and particulate whey protein emulsion gels," Journal of Food Science, vol. 69, no. 9, pp. S333-S339, 2004.
[22] M. Bourne, Food Texture and Viscosity: Concept and Measurement, Academic Press, 2002.

[23] M. I. González-Martín, J. M. Hernández-Hierro, I. Revilla et al., "Differentiation of organic and non-organic ewe's cheeses using main mineral composition or near infrared spectroscopy coupled to chemometric tools: a comparative study," Talanta, vol. 85, no. 4, pp. 1915-1919, 2011.

[24] D. L. Van Hekken, Y. W. Park, and M. H. Tunick, "Effects of reducing fat content on the proteolytic and rheological properties of Cheddar-like caprine milk cheese," Small Ruminant Research, vol. 110, no. 1, pp. 46-51, 2013.

[25] S. Awad, A. N. Hassan, and K. Muthukumarappan, "Application of exopolysaccharide-producing cultures in reduced-fat Cheddar cheese: texture and melting properties," Journal of Dairy Science, vol. 88, no. 12, pp. 4204-4213, 2005.

[26] M. H. Tunick, "Rheology of dairy foods that gel, stretch, and fracture," Journal of Dairy Science, vol. 83, no. 8, pp. 1892-1898, 2000.

[27] A. S. Szczesniak, "Texture is a sensory property," Food Quality and Preference, vol. 13, no. 4, pp. 215-225, 2002.

[28] A. Bryant, Z. Ustunol, and J. Steffe, "Texture of cheddar cheese as influenced by fat reduction," Journal of Food Science, vol. 60, no. 6, pp. 1216-1219, 1995.

[29] D. E. Johnston, "Application of polymer cross-linking theory to rennet-induced milk gels," Journal of Dairy Research, vol. 51, no. 1, pp. 91-101, 1984.

[30] M. El-Bakry, E. Duggan, E. D. O’Riordan, and M. O’Sullivan, "Effect of cation, sodium or potassium, on casein hydration and fat emulsification during imitation cheese manufacture and post-manufacture functionality," LWT-Food Science and Technology, vol. 44, no. 10, pp. 2012-2018, 2011.

[31] B. Juan, A. J. Trujillo, V. Guamis, M. Buffa, and V. Ferragut, "Rheological, textural and sensory characteristics of highpressure treated semi-hard ewes' milk cheese," International Dairy Journal, vol. 17, no. 3, pp. 248-254, 2007.

[32] M. H. Tunick, K. L. Mackey, J. J. Shieh, P. W. Smith, P. Cooke, and E. L. Malin, "Rheology and microstructure of low-fat Mozzarella cheese," International Dairy Journal, vol. 3, no. 7, pp. 649-662, 1993. 

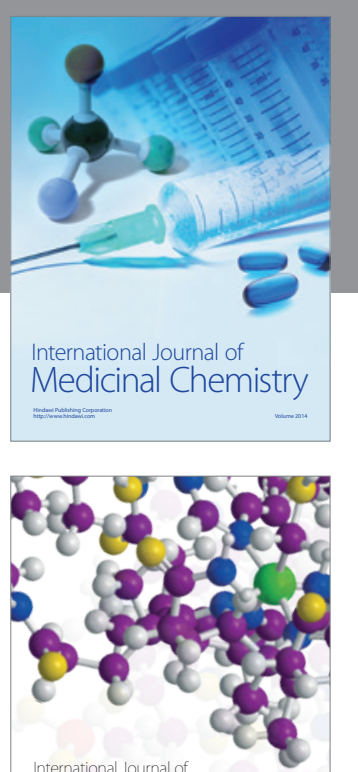

Carbohydrate Chemistry

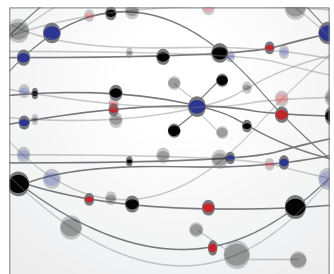

The Scientific World Journal
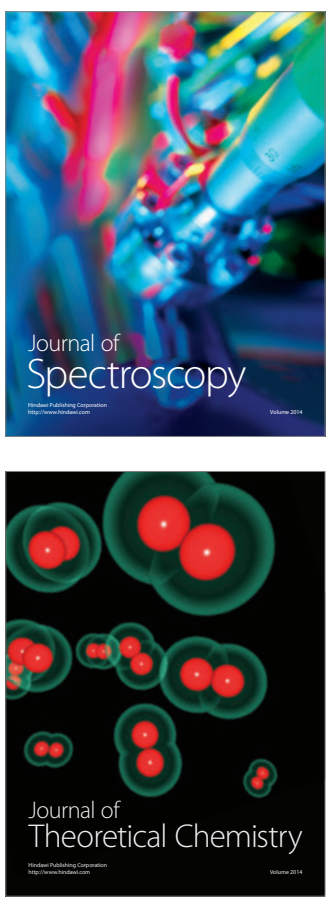
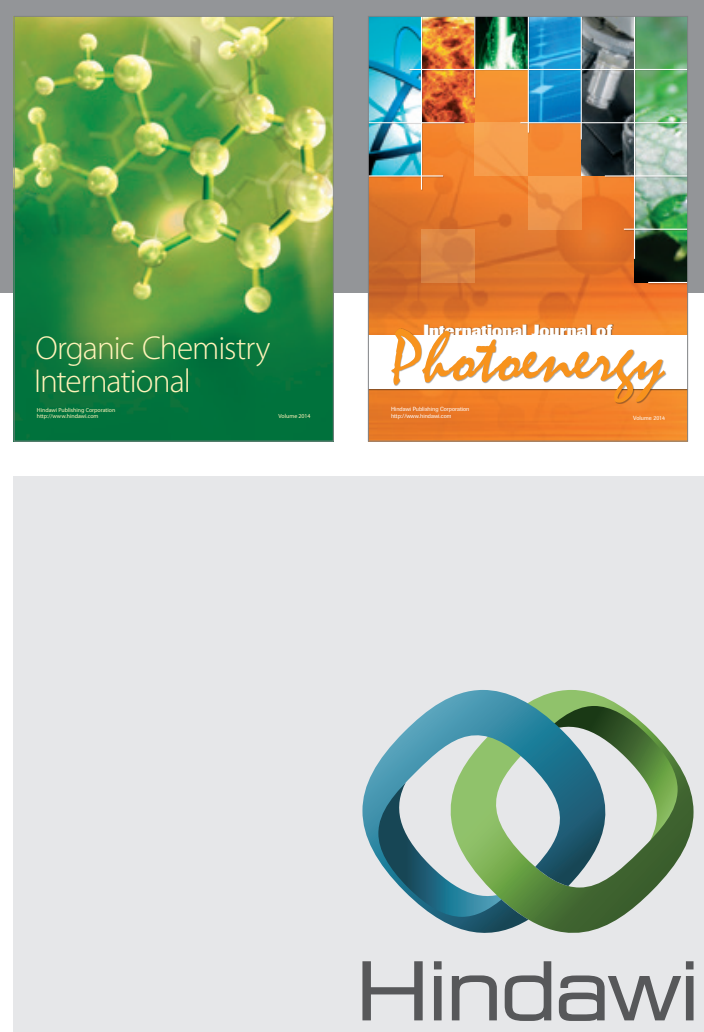

Submit your manuscripts at

http://www.hindawi.com

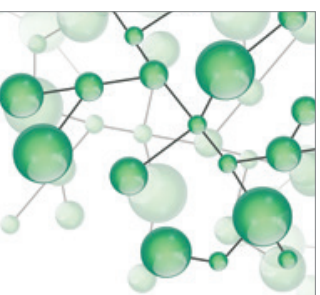

International Journal of

Inorganic Chemistry

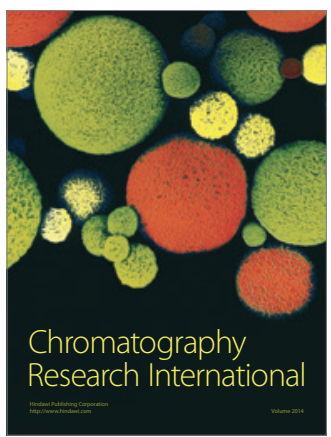

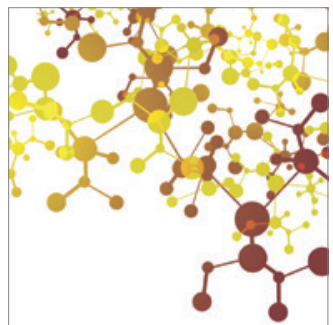

Applied Chemistry
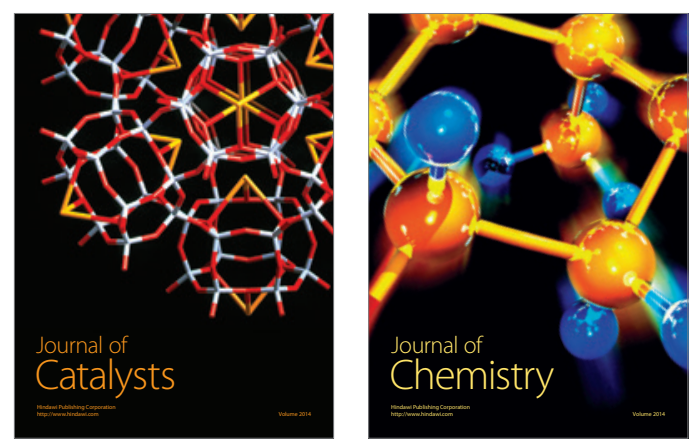
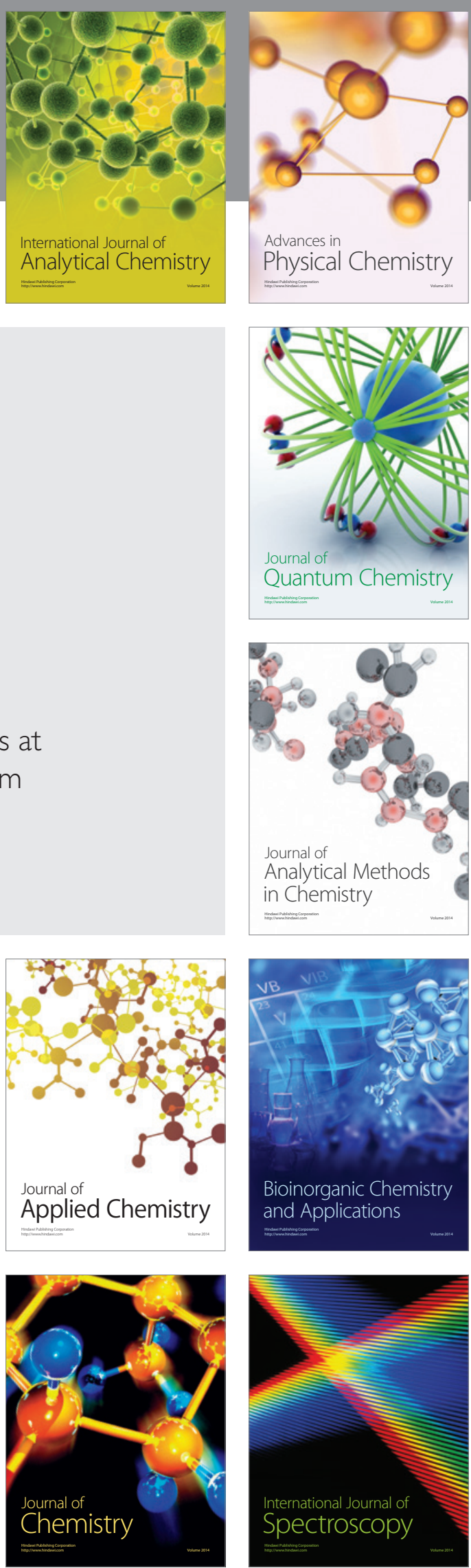